\title{
Analisis Teori Fungsionalisme pada Integrasi Kawasan Asia Selatan (Studi Kasus Konflik India-Pakistan di wilayah Kashmir)
}

\section{Tri Shinta Hd Putri}

Undergraduate Student of International Relations Department at Universitas Andalas shintauchinhdp@irestindonesia.org

\begin{abstract}
Abstrak
South Asia is a complex region. It is marked with the emergence and continuity of the conflict. India-Pakistan conflict is one of them. This conflict begun on 1947 and the biggest of conflict divided into three conflicts. Functionalism according to David Mitrany in "A Working Peace System" believes that Region Integration is trusted to make the conflict lower and good relation among state. This perception applied on 1985 in South Asia, which known with SAARC (The South Asian Association for Regional Cooperation). The fact, this conflict still continues till today. However, this paper seeks for the analysis of how's functionalism theory explain the conflict of India-Pakistan on the regional integration: is that the conflict form an ideal integration of Sout Asia and decline the conflict, or conversely. Furthermore, the result of this research describes that Functionalism is not success on explaining South Asia integration, which means the India-Pakistan conflict still exist and the real integration among member states still not exist yet.
\end{abstract}

Keyword: Functionalism, Regional Integration, India-Pakistan Conflict

\section{A. Latar Belakang}

Regionalisme atau integrasi kawasan merupakan salah satu kajian yang banyak diperbincangakan di dalam hubungan internasional. Paradigma yang paling dini dalam menganalisis integrasi kawasan adalah pendekatan fungsionalisme. Pendekatan ini lahir pasca Perang Dunia II seiring dengan munculnya pendapat bahwa sentralisasi peran serta sifat egosentris dari negara dalam hubungan internasional telah menyebabkan peperangan di dunia. Sehingga, seorang ahli yang bernama David Mitrany kemudian mengemukakan sebuah pemikiran yang disebut dengan Working Peace System. Salah satu argumentasi dari pemikiran ini adalah bahwa dalam menciptakan ketaraturan dan perdamian dunia diperlukan peran aktor non-negara. Dalam konteks regional, negara-negara yang tergabung dalam kawasan akan 
melakukan intergasi yang didasarkan pada kepentingan dan kebutuhan bersama sekaligus menyelesaikan berbagai permsalahan yang dihadapi. Intergasi tersebut didasarkan pada hal-hal yang bersifat non-politik seperti keamanan, ekonomi, budaya, lingkugan atas dasar kesamaan fungsi. ${ }^{1}$ Disisi lain, menurut fungsionalis kedaulatan negara memang masih dikaui, namun terdapat aktor lain yang sejajar dengan negara. Aktor tersebut kemudian memainkan peran yang setara dengan negara dalam integrasi.

Kawasan yang masih berlum beranjak dri permasalaan mendasar seperti keamanan adalah Asia Selatan. Konflik mainstream di kawasan ini adalah konflik wilaah antara India dan Pakistan dalam memperebutkan wilaah Kashmir. Konflik ini bermula ketika kedua negara saling memberikan klaim terhadap wilayah Khasmir di Utara India. Konflik ini telah berlangsung semenjak tahun 1947 ketika Pakistan menginvansi Khasmir yang dibalas dengan serangan militer India. Konflik Kashmir sendiir merupakan konflik paling klasik dan kompleks antara kedua negara. ${ }^{2}$ Dampak dari konflik Khasmir sangat berpengaruh tidak hanya bagi kedua negara, namun juga pada negara-negara SAARC. Menurut data Institute of Conflict Management, semenjak dimulainya konflik hingga tahun 2014 lebih dari 68.000 orang menjadi korban akibat dari konflik ini. ${ }^{3}$ Selanjutnya bagi integrasi kawasan sendiri, baik India dan Pakistan merupakan negara yang mempunyai peran penting di dalam SAARC sehingga secara otomatis konflik Khasmir ini akan berdampak kepada kawasan.

Sejatina, Asia Selatan sudah memulai berintegrasi pada 8 Desember 1985 dengan dibentuknya South Asian Association for Regional Coorporation (SAARC). SAARC didirikan oleh 8 negara-negara Asia Selatan yang meliputi India, Pakistan, Bangladesh, Sri Lanka dan Nepal. Keanggotaan SAARC kemudian bertambah ketika Afganishtan masuk menjadi anggota ke-9 pada tahun 2007. ${ }^{4}$ Pembentukan dari SAARC ini sendiri didasarkan pada kesadaran dari negara-negara di kawasan Asia Selatan bahwa terdapat berbagai macam tantangan yang tidak dapat diselesaikan di level domestik masing-masing negara. Oleh karena itu diperlukan adanya integasi kawasan yang di dalamnya terdapat penyatuan visi di dalam kerja sama regional di

\footnotetext{
${ }^{1}$ Mitrany, David, “ A Working Peace System”, Chicago Quadrangled Press, 1966, hal 101-103

${ }^{2}$ Majid, Abdul dan Mahboob Husain, “A Conflict Between India and Pakistan”,Journal of South Asian Studies, 2016, Vol.31, No.1, hal 149

${ }^{3}$ Raquel Amioca Abimola, "The Impact of Kahsmir Conlict on Indo-Pakistani Relations and It's Security Implications for The South Asian Region”, University of Kwazulu, 2014, hal 3

${ }^{4}$ Giri, Pratihiba, dkk, "A Study and Analysis of Challenges, Achievements and Hurldes Faced by SAARC Nations in Trade Integration and Growth", International Journal of Engineering Technology, Management and Aplied Sciences, 2015, Vol.3, No.1, hal 204
} 
berbagai bidang. Oleh karena itu di dalam awal pembentukannya, SAARC didirikan di dalam mencapai tujuan terselenggaranya keamanan, kebebasan (freedom), keadilan sosial (social justice) serta kesejahteraan ekonomi negara-negara kawasan Asia Selatan ${ }^{5}$. Berkaitan dengan tujuannya yaitu untuk menciptakan keamanan, pada faktanya dinamika di kawasan Asia Selatan masih diwarnai dengan berbagai macam konflik. Salah satu konflik yang cukup krusial adalah konflik khasmir yang melibatkan India dan Pakistan. SAARC sendiri telah melakukan berbagai upaya di dalam menyelesaikan konflik antara India dan Pakistan. Salah satunya adalah melalui SAARC Summits and Indo-Pakistan Relations. Kerangka yang sudah dimulai semenjak tahun 1985 ini memfasilitasi pemimpin dari kedua negara untuk bertemu dan membicarakan permsalahan kedua negara baik di dalam forum resmi ataupun tidak. ${ }^{6}$ Namun kemudian usaha yang dilakukan oleh SAARC ini tidak berhasil di dalam menyeleasaikan konflik antara India dan Pakistan dikarenakan konflik Kashmir masih berlangsung hingga sekarang. Ketidakberhasilan SAARC di dalam menyelesaikan konflik Kashmir ini sekaligus mematahkan pemikiran fungsionalisme yang memandang bahwa integrasi kawasan akan dapat mewadahi kepentingan dari negara dikawasan dan dapat menyelesaikan berbagai permasalahan guna mencapai perdamian dan stabilitas regional. Oleh karena itu, di dalam tulisan ini akan dijelaskan lebih lanjut mengenai aplikasi dari fungsionalisme di dalam menjelaskan intergasi kawasan di Asia Selatan khususnya di dalam kasus Konflik Kashmir antara India dan Pakistan.

\section{B. Pembahasan}

a. SAARC sebagai Integrasi Kawasan Asia Selatan

South Asia Association for Regional Cooperation (SAARC) merupakan organisasi kawasan yang berada di Asia Selatan yang terdiri dari 8 negara anggota. India, Bangladesh, Bhutan, Maldives, Nepal, Pakistan dan Sri Lanka merupakan negara-negara yang menjadi founding fathers berdirinya SAARC pada 8 Desember 1985 di Bangladesh. Sedangkan Afghanistan baru bergabung kemudian pada tahun 2007.

Berdirinya SAARC didasari dengan adanya kesadaran negara-negara SAARC akan pentingnya sebuah organisasi kawasan yang dapat mendorong dan meningkatkan kesejahteraan

\footnotetext{
${ }^{5}$ Sheel, Kant Sharma, "South Asian Regionalism : Prospect and Challenges”,Indian Forreign Journal Affairs, 2011, Vol.6, No,3, hal 305

${ }^{6}$ Naazer, Manzoor Ahmad, "SAARC Summits and Its Impact on Indo-Pakistan Relations" FWU Journal of Sciences, 2018, Vol.12, Hal.1, hal 67
} 
negara-negara anggotanya. Sebagaimana perdana mentri pertama india Jawaharlal Nehru dalam pidatonya sering menyebutkan bahwa pentingnya untuk membentuk kerjasama kawasan dalam mengatasi permasalahan diberbagai aspek seperti keamanan, ekonomi dan politik pada tahun 1946. ${ }^{7}$ Hal ini dikarenakan Asia Selatan memiliki sumber daya manusia dan alam yang melimpah, namun tidak terkelola dengan baik dikarenakan banyak konflik-konflik internal maupun ekternal yang terjadi. Sehingga fokus masing-masing negara lebih kepada keamanan militer daripada pembangunan dan kesejahteraan. Melihat hal ini muncul lah keinginan masingmasing negara untuk membentuk kerjasama kawasan untuk mewujudkan kesejahteraan bersama.

Gagasan untuk membentuk kerjasama kawasan ini pun sebenarnya telah mulai dibahas setidaknya dalam tiga pertemuan. Pertama pada tahun 1947, The Asian Relations Conference di New Delhi, kedua pada tahun 1950 dalam Baguio Conference di Filipina, dan terakhir pada tahun 1954 dalam The Colombo Powers Conference di Sri Lanka. ${ }^{8}$

Gagasan membentuk kerjasama kawasan ini kemudian diajukan oleh Presiden Bangladesh Ziaur Rahman pada tahun 1980. Hal ini memperoleh respon positif dari negaranegara SAARC lainnya yang ditandai dengan adanya pertemuan Menteri luar negeri di Colombo, Sri Lanka pada tahun berikutnya yang dihadiri 7 Negara yaitu Bangladesh, Bhutan, India, Pakistan, Maldives, Sri Lanka dan Nepal dimana masing-masing negara sepakat bahwa beridirnya kerjasama kawasan ini harus didasarkan pada saling percaya satu sama lain, pengertian dan appresiasi simpatik terhadap aspirasi nasional. Hingga akhirnya piagam SAARC disahkan pada tahun 1985 di Bangladesh. Pada masa tersebut, isu yang dibahas masih berfokus pada 5 bidang yaitu; Pertanian, Pembangunan pedesaan; Telekomunikasi; Meteorologi dan Kesehatan dan kependudukan

Kemudian isu-isu tersebut mulai berkembang dimana saat ini telah mencapai 11 isu yang di bahas dalam SAARC. Adapun arena kerjasama tersebut adalah ${ }^{9}$;

1. Pendidikan

2. Budaya dan Olahraga

3. Kesehatan, Populasi, kesejahteraan anak

4. Kelingkungan dan meteorologi

\footnotetext{
${ }^{7}$ SAARC: Its Evolution, Objectives, Constraints/Challenges and Prospects

${ }^{8}$ Shaheen, Irum. South Asian Association for Regional Cooperation (SAARC): Its Role, Hurdles and Prospects. IOSR Journal Of Humanities And Social Science (IOSR-JHSS).vol 15 issue 6 (2013)

${ }^{9}$ South Asian Association for Regional Co-operation.Britanica. (2018) diakses melalui https://www.britannica.com
} 
5. Pembangunan pedesaan

6. Pariwisata

7. Transpotasi

8. Ilmu pengetahuan dan teknologi

9. Komunikasi

10. Perempuan dalam pembangunan dan

11. Pencegahan penyeludupan dan penyalahgunaan obat-obatan

Dengan adanya arena kerjasama yang lebih luas tentunya SAARC mengharapkan dapat mencapai tujuan dibentuknya SAARC. Dimana SAARC sendiri memiliki 9 tujuan yaitu; ${ }^{10}$ Berdasarkan pasal 1 dalam piagam SAARC terdapat 8 tujuan dibentuknya SAARC yaitu; ${ }^{11}$

1. Untuk memajukan kesejahteraan dan meningkatkan kualitas hidup masyarakat Asia Selatan;

2. Untuk mempercepat pertumbuhan ekonomi, perkembangan sosial dan perkembangan kebudayaan di kawasan dan menyediakan untuk tiap-tiap individu untuk hidup bermatabat and untuk menyarinya bahwa mereka penuh dengan potensi;

3. Untuk memajukan dan memperkuat kepercayaan diri secara kolektif di antara negaranegara Asia Selatan;

4. Untuk memperbesar rasa saling kepercayaan, pemahaman, dan pengertian dari tiadari setiap masalah;

5. Untuk memajukan kerjasama yang aktif dan rasa saling menolong dalam perekonomian, sosial, kebudayaan, dan kajian riset dan teknologi;

6. Untuk memperkuat kerjasama dengan negara berkembang lainnya;

7. Untuk memperkuat kerjasama di antara anggota dalam forum internasional mengenai hal yang sedang terjadi;

${ }^{10}$ Compilation of SAARC Charter/Conventions/Agreements (1985-2016). (SAARC Secretary General 2016)

11 ibid 
8. Untuk bekerjasama dengan organisasi internasional dan regional yang memiliki target dan tujuan yang sama.

Selanjutnya SAARC juga memiliki prinsip dimana berdirinya kerjasama kawasan ini harus didasarkan pada prinsip kedaulatan, integritas wilayah, kemandirian politik dan tidak ikut campur dalam urusan dalam negeri negara anggota. Hingga saat ini Amerika Serikat, Australia, China, Jepang, Korea Selatan, Myanmar, Mauritius, Iran dan Uni Eropa telah menjadi pengamat dalam SAARC yang menunjukkan bahwa SAARC memiliki potensi yang besar sebagai organisasi kawasan.

\section{b. Konflik Kasmir dan Penanganannya dari SAARC}

Konflik Kashmir merupakan sebuah konflik yang berawal semenjak pasca kemerdekaan India dan Pakistan. Kemerdekaan ini dilatarbelakangi oleh Inggris yang meninggalkan India pada tahun 1947 yang menyebabkan perpecahan yang mana mayoritas pemeluk Hindu membentuk negara India dan pemeluk Islam membentuk negara Pakistan. Terpecahnya India dan Pakistan oleh pemerintah Inggris mengakibatkan konflik perebutan wilayah Kashmir. Konflik Kashmir bermula ketika masyarakat muslim di India membangun negara sendiri yaitu Pakistan. Persoalan muncul terkait dengan wilayah Kashmir yang penduduknya bermayoritas Muslim, tetapi pemimpinnya seorang Hindu.

Tanggal 15 Agustus 1947, Kashmir sebagai wilayah dari Negara Kepangeranan (Indian Princely States) diberikan pilihan oleh pemerintah kolonial Inggris untuk memilih menjadi bagian dari India atau Pakistan. Hari Singh sebagai seorang pemimpin Kashmir berpikir untuk tidak bergabung ke kedua negara tersebut dan ingin menciptakan negara baru . Namun, kemudian ia menyatakan bergabung dengan India tanpa persetujuan penduduknya. Hal ini membuat Pakistan dan penduduk Kashmir yang beragama Islam tidak menerima karena keputusan sepihaknya. Keputusan Hari Singh yang akhirnya menempatkan Kashmir sebagai wilayah sengketa dan berakhir dengan pembentukan garis gencatan senjata atau Case Fire Line. ${ }^{12}$

Konflik Kashmir mengakibatkan perang antara India dan Pakistan yang terjadi pada tahun 1947-1949, 1950-1965. Perang 1965 merupakan perang yang terbesar dan mengakibatkan

\footnotetext{
${ }^{12}$ Monica Krisna Ayunda and Rhoma Dwi Aria Y, M.Pd.Konflik India dan Pakistan Mengenai Wilayah Kashmir beserta Dampaknya (1947-1970).Universitas Negri Yogyakarta diakses pada tanggal 23 November 2018
} 
kekalahan pada Pakistan hingga perekonomian Pakistan mengalami kemerosotan. Konflik Kashmir juga berdampak pada bidang politik, salah satunya yaitu hubungan India dengan Pakistan yang memburuk. Dalam bidang ekonomi, India dan Pakistan mengalami perekonomian yang tidak stabil saat terjadinya konflik Kashmir pada 1947-1965 dan pasca konflik 1965. Di bidang sosial, India dan Pakistan mengalami pertambahan populasi penduduk akibat pengungsi dari Kashmir. ${ }^{13}$

Konflik Kashmir kemudian menjadi konflik perbatasan yang mana Kashmir merupakan wilayah yang subur dan dialiri oleh sungai-sungai yang dapat mempengaruhi kondisi geografis Asia Selatan. India dan Pakistan sama-sama mengklaim wilayah tersebut sebagai daerah mereka yang membuat pecahnya perang India-Pakistan yang juga melibatkan Cina sebagai salah satu negara yang juga mengambil bagian diwilayah konflik tersebut. Tudingan demi tudingan saling terjadi antara India dan Pakistan. Kedua negara ini menguasai wilayah Kashmir sepanjang 700 km namun India menuding Pakistan telah memberikan sebagian dari wilayah Kashmir ke Cina dan Cina mengklaim wilayah seluas 14.000 mil persegi sepanjang perbatasan timur laut India. ${ }^{14}$

Adanya konflik Kashmir ini menimbulkan tindakan bagi SAARC yang memiliki tanggung jawab untuk menyelesaikan masalah yang berada di kasawasan Asia Selatan. Konflik yang tak kunjung usai melibatkan negara kawasan Asia Selatan serta anggota SAARC yaitu India dan Pakistan. SAARC berperan sebagai organisasi internasional untuk menyelesaikan masalah tersebut melalui dua jalan yakni mediasi peredam konflik dan fasilitator proses negosiasi dan kesepakatan. ${ }^{15}$

a. Mediator sebagai mediasi

SAARC yang diketahui sebagai aktor netral dalam permasaahan konflik Kashmir berupaya selalu mendorong perundingan damai untuk memediasi kedua belah pihak yakni India dan Pakistan untuk menemukan jalan bersama mencari kedamaian di daerah Kashmir. Pada atahun 2006, SAARC memediasi India dan Pakistan untuk melakukan dialog damai pada KTT di Newdelhi, perundingan tersebut bertujuan untuk menyelesaikan persengketaan kedua belah pihak dengan permasalahan utama yakni keamanan dan isu terorisme di wilayah perbatasan. Perundingan yang dilakukan selama dua hari tersebut dinyatakan gagal karena terjadinya insiden penyerangan India yang menewaskan 5 masyarakat Sipil. Konflik terus

${ }^{13}$ Ibid hal 11

${ }^{14}$ Ibid hal 11

${ }^{15}$ http://repository.upnyk.ac.id/4530/1/abstrak.pdf diakses pada 23 November 2018 
bergulir hingga 2 tahun berikutnya yang mana pada tahun 2008 India menolak perundingan damai dengan pakistan setelah serangan-serangan di Mumbai November 2008, yang menewaskan 166 orang. Sejak itu, India berulang-ulang menolak imbauan Pakistan untuk dimulainya perundingan. Hingga pada tahun 2010 India dan pakistan dipertemukan kembali oleh SAARC dalam KTT Thimpu di Bhutan.

Perdana Mentri India Manmohan Singh dan Yousuf Raza Gilani bertemu selama 90 menit di sela-sela KTT Asosisasi bagi Kerjasama Regional delapan negara (SAARC) yang diselenggarakan di Thimphu. Kedua pemimpin itu sepakat menggelar pertemuan menteri luar negeri kedua negara untuk menyusun satu peta jalan bagi perundingan mendatang Upayaupaya yang dilakukan SAARC dalam mempertemukan kedua belah pihak nampaknya hingga saat ini belum berhasil. Upaya terakhir SAARC pada tahun 2015 merupakan salah satu upaya yang membawa dampak postif yang mana Pakistan dan India mengadakan perundingan diplomatik di Islamabad. Mereka membincangkan jalan keluar bersama terkait konflik di perbatasan. ${ }^{16}$

b. Sebagai fasilitator

Peran SAARC adalah menyediakan fasilitas untuk mengadakan pertemauan berupa pertemuan tahunan yang dikenal sebagai KTT SAARC untuk menyelesaiakan konflik anatara India dan Pakistan. ${ }^{17}$ Pertemuan SAARC selalu diadakan setiap tahunnya, salah satu pembahasan selain kerjasama ialah mencari solusi damai atas wilayah Kashmir. Upaya penyelesaian terus dilakukan meskipun ada kalanya pertemuan yang dihasikan menghasilkan perbedaan pendapat. SAARC mengupayakan pertemuan setiap tahun untuk terciptanya kerjasama kawasan yang stabil dan juga penyelesaian konflik antar anggota.

Berdasarkan pemaparan diatas, dapat dikatakan bahwa SAARC sebagai organisasi Asia Selatan yang bersifat netral sampai saat ini belum menemukan titik terang dalam penyelesaian konflik Kasmir. Dengan kata lain selama ini SAARC hanyalah wadah bagi wakil baik dari India maupun Pakistan untuk berunding dan mencoba menyelesaikan pertikaian mereka.

\footnotetext{
${ }^{16}$ Ibid

17 Mir, M. A. (2015).India -Pakistan; the Process of Conflict Resolution.Internasional Jourrnal of Innovative Research \& Development, 336
} 


\section{c. Teori Fungsionalisme (Regionalisasi Ideal versi David Mitrany)}

Pasca perang dunia II regionalisme sudah menjadi fenomena penting dalam melihat sistem internasional. Peter J. Katzenstein memaparkan bahwa saat ini sistem internasional didefinisikan sebagai interaksi antara kawasan dan regional power sehingga membuat dunia sebagai world of regions. ${ }^{18}$ Dalam kajian studi Ilmu Hubungan Internasional regionalisme menjadi salah satu perhatian utama karena merebaknya regionalisme di seluruh kawasan di dunia serta dinamika yang muncul dari waktu ke waktu. Awal kemunculan regionalisme dapat dilihat dari perkembangan European Coal and Steel Community (ECSC) di Eropa Barat pada tahun 1951. Lahirnya ECSC memicu kawasan lain untuk membentuk regionalisme yang sama, seperti di kawasan Amerika Latin, Asia Tenggara, dan Afrika Timur. Adanya perkembangan yang pesat mengenai hadirnya regionalisme di era 1950-an hingga 1960-an membuat fenomena ini menjadi suatu fokus kajian baru bagi studi Ilmu Hubungan Internasional, yaitu studi mengenai kerja sama regional dan regionalisme. Pasca perang dingin, fenomena regionalisme kembali muncul yang ditandai dengan kebangkitan integrasi Eropa Barat dengan membentuk the Single European Act. Selain itu, fenomena ini juga menyebar dengan munculnya berbagai regionalisme baru seperti Asia Pacific Economic Cooperation (APEC), North American Free Trade Agreement (NAFTA), Common Market of the South (MERCOSUR). ${ }^{19}$

Hurell mendifinisikan regionalisme sebagai seperangkat kebijakn oleh satu atau lebih negara untuk mempromosikan kemunculan unit regional yang kohesif dan mendominasi pola hubungan antara negara dengan kawasan tersebut dan dengan seluruh dunia serta membentuk dasar pengorganisasian kebijakan dalam kawasan yang mencakup berbagai isu. ${ }^{20}$ Regionalisme juga dapat diartikan sebagai kebijakan yang dibentuk dari unit regional yang kohesif. Selain itu, regionalisme sebagai proyek yang dipimpin oleh negara atau state-led project untuk mengorganisasikan ulang suatu kawasan regional tertentu dalam cakupan ekonomi dan politik. ${ }^{21}$ Dalam regionalisme adanya konektivitas, ketergantungan, dan hubungan kerja sama dalam berbagai bidang untuk mengintegrasikan negara-negara dalam suatu kawasan tertentu.

\footnotetext{
${ }^{18}$ Peter J. Katzenstein, A World of Regions: Asia and Europe in the American Imperium (Cornell University Press, 2005), 1.

19 Jeans-Uwe Wunderlich, Regionalism, Globalisation, and International Order; Europe and Southeast Asia (Hampshire: Ashgate Publishing Limited, 2007),1.

${ }^{20}$ Andrew Hurrell, "Latin America in the New World Order: A Regional Bloc of the America", International Affairs 68, no 1 (1992):123.

21 lbid.
} 
Dalam melihat fungsi dari regionalisme tersebut, dapat dilihat dari kacamata kerangka teori fungsionalisme dan neo-fungsionalisme. Pada tulisan ini, penulis akan fokus melihat isu dalam kacamata teori fungsionalisme. Teori fungsionalisme lahir anatara pasca perang dunia I, dengan pakar utama yaitu David Mitrany. Dimana teori fungsionalisme yang dikemukakan oleh David Mitrany menekankan pada peran organisasi iternasional. Mitrany percaya bahwa organisasi internasional merupakan working peace system, yaitu organisasi internasional dapat meningkatkan intensitas kerja sama negara anggotanya, sehingga tercipta interdependensi di antara negara-negara anggota yang kemudian dapat mengurangi konflik. Pemikiran ini muncul karena adanya sebuah asumsi bahwa negara bukan satu-satunya aktor dalam tatanan internasional, karena kepentingan negara adalah alasan kenapa perang itu terjadi. Masuknya sebuah negara dapat mengurangi kedaulatan sebuah negara karena negara tersebut harus menyesuaikan kebijakan domestiknya sesuai dengan aturan yang berlaku di organisasi internasional. Melemahnya kedaulatan suatu negara merupakan hal yang baik, dengan demikian kerjasama dan integrasi dapat tercipta. ${ }^{22}$

Berbeda dengan teori realis yang menekankan pada national interest, teori fungsionalisme lebih fokus pada common interest dan kebutuhan bersama. Mitrany berpendapat bahwa terdapat kebutuhan yang sifatnya cross border dan cara terbaik untuk menyelesaikannya dengan joint governement. Kerjasama yang saling menguntungkan ini akan lebih mudah dicapai apabila fokus pada isu-isu non-politis. Cakupan dari fungsionalisme tidak hanya terbatas pada aktor negara, tetapi juga mencakupi aktor non-negara. Fungsionalisme mengusulkan untuk membangun otoritas yang berbasis pada fungsi dan kebutuhan, serta mengesampingkan ide mengenai state power dan pengaruh politik. ${ }^{23}$

Dalam kerangka berpikir fungsionalisme, integrasi adalah sebuah solusi yang ditawarkan dalam dinamika regionalisme. Hal ini dapat dikatakan demikian karena integrasi dilakukan oleh aktor negara maupun aktor non-negara. Integrasi dapat diartikan sebagai kerangka berpikir bebas yang melibatkan segala aktor dalam pencapaian tujuan. Dimana dalam membuat ataupun menjalankan suatu kebijakan, integrasi dilakukan berdasarkan kepentingan dan kebutuhan bersama. Dengan adanya kepentingan dan kebutuhan bersama, akan tercapai regionalisme yang

\footnotetext{
${ }^{22}$ M. Griffiths, Fifty Key Thinkers in International Relations, edisi Bahasa Indonesia Lima Puluh Pemikir Studi Hubungan Internasional, diterjemahkan oleh Mahyudin, PT Raja Grafindo Persada, Jakarta, 2001. P. 239. ${ }^{23} \mathrm{lbid}$.
} 
stabil karena negara tidak akan arogan dan egois mengenai kepntingan nasionalnya serta menurunkan sedikit kedaulatannya. Bagi fungsionalisme integrasi dapat diartikan sebagai bentuk integrasi berdasarkan fungsi dalam bidang-bidang non-politik (lingkungan, ekonomi, sosial, dan budaya) yang akan membentuk keterikatan dan saling ketergantungan satu sama lain. Dengan tercapainya keterikatan dan saling ketergantungan maka hal ini akan meminimalisir terjadinya konflik. Tercapainya fungsi dan tujuan yang sama dari negara-negara dalam regionalisme tersebut, teori ini berasumsi akan terciptanya intergarasi dalam negara-negara tersebut.

Dalam teori fungsionalisme, isu politik dikesampingkan dalam hal integrasi karena lebih menekankan pada kesamaan fungsi dan tujuan dalam bidang lain. Selain itu, lembaga yang dibentuk didasarkan pada fungsi yang sama antar aktor yang bersepakat dalam pelaksanaan fungsi dan tujuan tersebut. Teori fungsionalisme juga menekankan intervensi serta sabota negara dihilangkan atas dasar kesamaan tujuan akhir. Dengan begitu akan terciptanya kerjasam regional yang baik dan meminimalisir terjadinya konflik. dengan adanya hubungan yang erat didasarkan pada fungsi dan tujuan yang sama, maka negara akan menurunkan sedikit kedaulatannya dan tunduk pada aturan integrasi kawasan yang sudah disepakati demi pencapaian tujuan bersama.

d. Analisis: Komparasi Teori Fungsionalisme dengan Regionalisasi di Kawasan Asia Selatan

Fungsionalisme berusaha untuk membuat negara saling bekerja sama dimulai dari hal-hal yang kecil misalnya masalah lingkungan, kesehatan, dan lain sebagainya sehingga negara dapat bekerjasama dengan lebih menekankan pada kepentingan secara kolektif dan dengan begitu dapat diharapkan terciptanya perdamaian dan kesejahteraan. ${ }^{24}$ Kaum fungsionalisme menawarkan sebuah solusi bahwa tidak diperlukan batas-batas wilayah, sehingga kerjasama dapat meluas hingga mencapai integrasi. ${ }^{25}$ Namun pada intinya teori fungsionalisme mengutamakan kepentingan bersama serta tujuan bersama dalam proses integrasi. Sehingga teori ini juga menjadi pendekatan yang penting dalam institusi internasional, karena dianggap sebagai pencipta kedamaian dan kesejahteraan bagi para anggotanya.

\footnotetext{
24 James A. Caporaso, The European Community and Regional Integration Theory, Department of Political Science University of Washington Seattle, Hal.3

25 Hettne, Bjorn and Fredrik Söderbaum. 2008. “The Future of Regionalism: Old Divides, New Frontiers" in Regionalisation and Global Governance: the Taming of Globalisation?, by Andrew F. Cooper, Christopher W. Hughes and Philippe De Lombaerde (eds). London: Routledge. Hal. 63
} 
Dalam penerapan teori fungsionalisme dalam integrasi kawasan, kawasan Asia Selatan pada Desember 1985 membentuk suatu kerjasama regional yang bernama South Asian Association for Regional Cooperation (SAARC). Organisasi internasional tingkat regional ini memiliki fungsi dan tujuan dalam penerapannya, disamping tujuan utamanya yaitu, memajukan kesejahteraan masyarakat di kawasan Asia Selatan. SAARC juga membahas isu terorisme yang melanda dunia, isu keamanan, konflik bilateral negara anggota dan juga multilateral, ekonomi dan lainnya.

Pertumbuhan regionalisme di Asia Selatan mengalami keterlambatan meski telah lama dibentuk SAARC. Lyon berpendapat bahwa Asia Selatan merupakan "a region without regionalism". ${ }^{26}$ Lambatnya pertumbuhan kawasan Asia Selatan disebabkan beberapa kondisi di kawasan tersebut, yang mana coba dijelaskan oleh Dash pada tulisannya yang berjudul Regionalism in South Asia: Negotiating Cooperation, Institutional Structures, diantaranya ;

- Negara-negara Asia Selatan memiliki karakteristik yang sama. Lebih dari separuh dari orang miskin di dunia hidup di kawasan ini. Pendapatan per kapita di kawasan ini juga masih tergolong rendah. Disparitas antara yang miskin dan yang kaya, ketersediaan tenaga medis, obat-obatan, air minum, dan fasilitas sanitasi yang terbatas menyebabkan masalah kemiskinan semakin besar

- Negara-negara Asia Selatan memiliki tingkat pertumbuhan penduduk yang tinggi selama 40 tahun terakhir. Diperkirakan hingga tahun 2010, jumlah populasi di Asia Selatan akan mencapai seperempat dari seluruh jumlah populasi dunia (Dash, 2008).

- Negara-negara Asia Selatan memiliki tingkat pertumbuhan ekonomi yang rendah jika dibandingkan dengan Asia Timur dan ASEAN, baik dalam bidang industri maupun agrikultur. Hal ini semakin diperparah dengan disparitas yang jauh antara kawasan yang berbeda dan strata masyarakat yang berbeda dalam satu kawasan Asia Selatan

- Konflik domestik yang terjadi di negara Asia Selatan. Contohnya adalah perang saudara di Sri Lanka.

- Konflik yang terjadi antar negara Asia Selatan, yaitu konflik berkepanjangan antara India dan Pakistan. Sejarah mencatat bahwa India dan Pakistan selalu terlibat konflik mulai

\footnotetext{
${ }^{26}$ Dash, Kishore C. (2008) Regionalism in South Asia: Negotiating Cooperation, Institutional Structures. New York: Routledge, Hal. 346
} 
dari sengketa Kashmir antara Islam Pakistan dan Hindu India hingga saling menyalahkan masalah terorisme dan masalah sumber daya alam. Konflik lainnya adalah antara Afghanistan dan Pakistan tentang garis batas, India dan Bangladesh tentang sungai Gangga dan imigrasi illegal Bengalis ke India, Nepal dan Bhutan tentang pengungsi Bhutan di Nepal, dan sebagainya (Ahmed dan Bhatnagar, 2008).

- Negara-negara Asia Selatan tidak memiliki common external threat. Hal ini menyulitkan para pemimpin kawasan ini untuk bekerja dengan strategi keamanan regional yang sama. Ancaman justru datang dari tetangga sendiri, yaitu negara sesama kawasan Asia Selatan

- Di antara negara-negara Asia Selatan, India adalah negara yang paling besar secara geografi dan juga secara ekonomi. Negara-negara kawasan tersebut mengkhawatirkan bahwa setiap perjanjian perdagangan hanya akan memberikan keuntungan bagi India dan barang-barang India akan mendominasi pasar regional. Hegemoni India, kekurangpercayaan di antara negara Asia Selatan, dan tentangan Pakistan terhadap dominasi India di Asia Selatan membuat pertumbuhan regionalisme Asia Selatan semakin sulit

Hambatan-hambatan akibat kondisi yang dialami kawasan Asia Selatan, membawa keterlambatan perkembangan negara-negara kawasan meski telah dibentuk organisasi tingkat regional, SAARC.

C. Kesimpulan 


\section{Daftar Pustaka}

Giri, Pratihiba, dkk, "A Study and Analysis of Challenges, Achievements and Hurldes Faced by SAARC Nations in Trade Integration and Growth", International Journal of Engineering Technology, Management and Aplied Sciences, 2015, Vol.3, No.1, hal 204

Majid, Abdul dan Mahboob Husain, “A Conflict Between India and Pakistan”,Journal of South Asian Studies, 2016, Vol.31, No.1, hal 149

Mitrany, David, “A Working Peace System”, Chicago Quadrangled Press, 1966, hal 101-103

Sheel, Kant Sharma, "South Asian Regionalism : Prospect and Challenges",Indian Forreign Journal Affairs, 2011, Vol.6, No,3, hal 305

Naazer, Manzoor Ahmad, "SAARC Summits and Its Impact on Indo-Pakistan Relations" FWU Journal of Sciences, 2018, Vol.12, Hal.1, hal 67

M.A,Mir.(2015).India -Pakistan; the Process of Conflict Resolution.Internasional Journal of Innovative Research \& Development, 336

Ayunda, Monica Krisna and Rhoma Dwi Aria Y.Konflik India dan Pakistan Mengenai Wilayah Kashmir beserta Dampaknya (1947-1970).Universitas Negri Yogyakarta

http://repository.upnyk.ac.id/4530/1/abstrak.pdf diakses pada 23 November 2018

Katzenstein, Peter J. 2005. A World of Regions: Asia and Europe in the American Imperium. Cornell University Press.

Wunderlich, Jeans-Uwe. 2007. Regionalism, Globalisation, and International Order; Europe and Southeast Asia. Hampshire: Ashgate Publishing Limited.

Hurrell, Andrew . 1992. Latin America in the New World Order: A Regional Bloc of the America, International Affairs 68, no 1.

Griffiths, M. 2001. Fifty Key Thinkers in International Relations, edisi Bahasa Indonesia Lima Puluh Pemikir Studi 
NN. SAARC: Its Evolution, Objectives, Constraints/Challenges and Prospects

Shaheen, Irum. 2013. South Asian Association for Regional Cooperation (SAARC): Its Role, Hurdles and Prospects. IOSR Journal Of Humanities And Social Science (IOSRJHSS).vol 15 issue 6

NN. South Asian Association for Regional Co-operation.Britanica. (2018) diakses melalui https://www.britannica.com

SAARC Secretary General. 2016. Compilation of SAARC Charter/Conventions/Agreements (1985-2016).

Hettne, Bjorn and Fredrik Söderbaum. 2008. "The Future of Regionalism: Old Divides, New Frontiers" in Regionalisation and Global Governance: the Taming of Globalisation?, by Andrew F. Cooper, Christopher W. Hughes and Philippe De Lombaerde (eds). London: Routledge

Dash, Kishore C. 2008 Regionalism in South Asia: Negotiating Cooperation, Institutional Structures. New York: Routledge

James A. Caporaso. 1993. The European Community and Regional Integration Theory, Department of Political Science University of Washington Seattle 